\title{
Initiating university-industry collaborations in developing countries
}

Link to publication record in Manchester Research Explorer

\section{Citation for published version (APA):}

Malik, K., \& Wickramasinghe, V. (2015). Initiating university-industry collaborations in developing countries. Paper presented at 5th Annual International Conference on Innovation \& Entrepreneurship (IE 2015).

\section{Citing this paper}

Please note that where the full-text provided on Manchester Research Explorer is the Author Accepted Manuscript or Proof version this may differ from the final Published version. If citing, it is advised that you check and use the publisher's definitive version.

\section{General rights}

Copyright and moral rights for the publications made accessible in the Research Explorer are retained by the authors and/or other copyright owners and it is a condition of accessing publications that users recognise and abide by the legal requirements associated with these rights.

\section{Takedown policy}

If you believe that this document breaches copyright please refer to the University of Manchester's Takedown Procedures [http://man.ac.uk/04Y6Bo] or contact uml.scholarlycommunications@manchester.ac.uk providing relevant details, so we can investigate your claim.

\section{OPEN ACCESS}




\section{Initiating university-industry collaborations in developing countries}

\author{
Khaleel Malik \\ MIoIR/ Manchester Business School \\ University of Manchester \\ Manchester, UK.
}

\author{
Vathsala Wickramasinghe \\ Department of Management of Technology \\ University of Moratuwa \\ Moratuwa, Sri Lanka.
}

\begin{abstract}
University and industry collaborative relationships are now widely practiced in many countries and are increasingly important in some developing countries. This paper aims to show what is similar and what is different about the relationships between how universities interact with industrial firms in developing as contrasted with advanced industrial economies. We report some initial findings from our research project conducted in Sri Lanka. Our survey of universities and some industry representatives shows that although universities might lack infrastructure, skills and resources required to fully support academic entrepreneurship, there is evidence of some interesting collaborative initiatives starting up. We also present some suggestions for promoting these types of interactions based on evidence gathered from holding a mini workshop with staff representing a variety of different industry sectors.
\end{abstract}

Keywords - universities; collaboration; industry; developing countries; Sri Lanka

\section{INTRODUCTION}

In the area of innovation and entrepreneurship research and higher education research, the triple helix model has been commonly used as a framework for understanding interactions between key actors in different innovation systems. One fundamental statement in the triple helix thesis is that the triple helix relations between academia-industry-government relations are indispensable conditions for fostering innovation and growth [1]. In this research, we focus on the interaction between universities and industry in developing countries as two of the major actors of any national innovation system. In examining the transition from a research university to an entrepreneurial university, Etkowitz [2] affirms that the academic enterprise is transformed in parallel, sometimes leading, other times lagging the transition to a knowledgebased economy.

University-industry collaboration is often initiated through contacts with established knowledge and actor networks, and to focus on the manipulation of codified knowledge to produce new technical devices and instruments [3, 4]. In emergent industries, cooperation with universities is more often aimed at enhancing new knowledge development. Firms are more likely to collaborate with universities to access new knowledge developments and obtain scientific support for new product development [5]. It is likely that this collaboration will be based on new and informal contacts with employees and students playing important roles [6].

This paper focusses on how developing countries have attempted to initiate collaboration between universities and industrial firms. Universities are constantly looking for new ways to remain relevant actors in the knowledge economy, which means they need to secure some external funding sufficient to cope with the increasing costs of running and maintaining research laboratories. On the other hand, industrial firms are exploring ways of keeping abreast of technological progress in a highly uncertain competitive environment. Hence both of these actors can help each other via a number of different types of interactions, but we are mainly going to analyse research based collaborations in this paper. Although there is abundant evidence to suggest that different forms of knowledge transfer occurs between universities and industry, for example via informal contacts, personnel mobility, consulting relationships and joint research projects [7], most of this evidence is reported from developed country experiences. Therefore we aim to provide some insights into this important activity from a few developing country experiences utilising both secondary and primary data sources.

\section{INDUSTRIAL FIRM LINKAGES WITH UNIVERSITIES}

As innovative activities inside of firms have become more professionalized, and some university research has become more specialized, universities are playing an important role in providing the trained researchers for firms in some sectors to perform their innovative activities. At the same time, firms have found it essential to have processes in order to benefit from progress in those longer-term research programs in universities in fields that have impacts on their present and future business activities.

The range of interactions between universities and firms is considerable. At one extreme, there might be fundamental research undertaken by a university researcher that leads to a discovery, its practical importance is recognized by a business firm, which may collaborate with the university researcher in order to exploit it. This happens most often in science-based industries including the chemical, biotechnology and pharmaceutical sectors, where the focus is on the discovery of interesting and useful synthetic molecules. At the other extreme, the provision of trained researchers, familiar with the 
latest research techniques and integrated in international research networks, is important to firms. Thus, even if university research in mechanical engineering has fewer direct applications than research in chemistry, it still provides mechanical engineers trained (for example) in those simulation and modelling techniques that are increasingly important in the design and development of automobiles and aero-engines [8].

When analyzing university-industry collaborations, we need to acknowledge that no single university is likely to have the complete set of skills a company may require. Crossinstitutional research may be needed to satisfy a diverse or multifaceted set of needs within a single area. Hence such collaborations can bring benefits and challenges. The benefits might be concrete, in the form of a flow of marketable innovations, and 'soft', in, for example, the development of informal linkages between university research staff and company $R \& D$ workers or other company staff [9]. Here we also need to consider whether there is any link between firm size and the advantages and outcomes of university-industry collaborations in terms of stimulating innovation in firms. Santoro and Chakrabarti [10] propose that large firms would typically focus upon non-core technologies and non-core business areas when interacting with universities and academic scientists, whereas small firms would focus upon core technologies and business areas. Link and Rees [11] argue that small firms have an innovation advantage over large firms, and that the small firms are better able to benefit from relationships with universities. In contrast, Fontana, Geuna and Matt [12] find that large firms are more likely to interact with universities (i.e. have a higher propensity to sign collaborative agreements).

Although universities might seem to fulfill broadly similar functions in the innovation systems of most industrial economies, the importance of their role varies considerably across developed and developing economies, as this is influenced by the structure of domestic industry, the size and structure of other publicly funded research performers, and numerous other factors. Hence we need a better understanding of why industrial firms in developing countries would benefit from linkages with universities, especially in a resource constrained environment.

\section{SOME DEVELOPING COUNTRY INSIGHTS}

When analyzing university-industry collaborations in developing countries, one needs to appreciate the fact that applying a conceptual framework like the National Innovation System (NIS) theory or triple helix model in this context may very well miss some innovation system nuances peculiar to these economies. For example, often research and development efforts in developing countries might develop much more slowly compared to developed economies due to the type of research facilities available, there are usually fewer technology driven industries and more low technology based sectors (e.g. agriculture and craft industries) - possibly hindering the application of the NIS concept as a development tool and strategy. Now we provide some country specific insights of university-industry collaborations from a few Asian developing countries, based on previous studies, before moving onto present our empirical research insights from Sri Lanka later in this paper.

\section{A. Pakistan}

Although Pakistan has been a good producer and exporter of products, these are mainly from the agriculture, leather and textile sectors. The industrial sector in Pakistan is lagging behind many other developing countries, especially in terms of its infrastructure and skilled workforce. Mostly industries operate at minimal labor, often with few graduates or highly qualified skilled professionals, and are private sector entities, with very poor R\&D facilities and very few academic linkages of note [13].

Some developing and industrialised economies have witnessed the emergence of new stakeholders concerned by issues related to innovation and technology transfer in recent years. These organisations range from associations of entrepreneurs or innovators, to business clubs or associations, to specialised institutes or technology parks. This has led to a gradual acknowledgement by governments of the importance of innovation and entrepreneurship as a policy theme. One clear implication for Pakistan is a need for a strong science and technology policy and for other policy areas (e.g. higher education, IT, agriculture) to acknowledge the importance of innovation across different stakeholders in the country in order to help lay the foundations for university-industry collaborations [14].

Knowledge-based economies develop by sharing information and knowledge transfer. In order to develop the scientific and research culture across Pakistan, Gul and Ahmad [15] state that it is important to socialize the scientific activities, in the form of conferences, seminars, symposia, workshops and small training initiatives. These provide the important platform for sharing of information to other members of the community. Industrial communities get to know about the plethora of research progress across different universities, which assist in the collaboration as per their product development.

Relationships between universities and industrial firms in Pakistan have developed very slowly over recent times, mainly due to divergent viewpoints concerning the merits of such collaborations. Industries demand research in practical fields where as universities prefer research in their own respective scientific and technological areas. But with the passage of time, both industry and universities are realizing the increasing demand for their joint participation in research activities. This has partly been initiated by the Higher Education Commission of Pakistan's project University-Industry Interaction (UII), which was launched in 2005. However there is no evaluation report in the public domain, which proves any success or limitations of this project [16].

\section{B. Thailand}

Here we provide an example of how one universityindustry partnership has unfolded in Thailand. The King Mongkut University of Technology-Thonburi (KMUTT), is a public university that shifted to an autonomous status in the mid-1990s. KMUTT is a relatively small engineering university, which has worked to put in place the systems- 
financial, personnel, overall governance, etc.- - to create a cadre of professional academics that are incentivized to undertake a mix of top-quality academic work as well as reach out more to the community and to business. The path has not been easy, but most staff appears to have been comfortable with the transition and have confidence in the strong leadership of KMUTT's presidents to date. One change in the governance structure during early-2000s was the recruitment of an outside marketing-style person from business to run the university's institute devoted to matching university resources with demand from outside [17]. This type of senior management change might help a university to lay the foundations for external engagement across a spectrum of activities with business and industry.

From the Thai Hard Disk Drive (HDD) industry, we learn that the intermediaries play an important consulting, brokering, and mediating role to help facilitate university-industry collaboration for this sector in Thailand. According to a survey conducted by Sutthijakra and Intarakumnerd [18], these intermediaries help alleviate systemic failures by building the formal network of university and industry, developing human resources and providing resources (i.e. information, training, testing and funding) to university and industry. As a result, interactions and relationships in university-industry linkages are deepened and strengthened.

At a more widespread level, firms operating in Thailand have generally not exhibited strong interest in universityindustry collaborations. This perhaps reflects the fact that Thailand's strategy of linking protection in the domestic market with exports of natural resources and low-wage manufactured goods translates into low levels of competitive threats to Thai-based firms and, as a result, low levels of enthusiasm to pursue partnerships with universities. This is less the case for firms, such as Toyota, which operate in mediumtechnology and high-technology areas and are able to draw on R\&D from outside the country or to pursue such activities inhouse [19]. Even if the private sector was more eager to link up with universities, Thailand's educational infrastructure has, apart from a few exceptions, exhibited neither the incentives nor institutional capacities for such linkages. There are numerous characteristics of Thai universities themselves that impede closer ties to the private sector. For example, finding the appropriate person to manage the interface is critical. In general, university staff operate on a timeframe that is tied to the semester or to the thesis writing period of students, whereas private sector businesses expect a much quicker turnaround. Some academics remain suspicious of the development of close links with the private sector [19]. In the past, links between Thai universities and the private sector have been based purely on informal consultancy services. The main aim of the professors has been to obtain an additional personal income to enhance the low salaries in the public sector [20].

\section{INSIGHTS FROM SRI LANKA}

\section{A. University-industry interactions in Sri Lanka}

Lying off the southern tip of India, the tropical island of Sri Lanka has a population of approx. 22 million people. After more than 25 years of civil conflict, which ended in May
2009, the country can now look forward to improved economic and social prosperity. Sri Lanka is a developing economy based largely on agriculture, services, and light industry. The service sector is the largest sector of the Sri Lankan economy, employing $45 \%$ of the workforce. Tourism, banking, finance, and retail trade are the major components of the service sector [21]. According to the UNESCO Sri Lanka Country Report [22], Sri Lanka has 15 conventional universities. There are two other universities, one under the Ministry of Defence and the other under the Ministry of Vocational Technology. The funds channelled by the government amount to less than $0.5 \%$ of GDP; the universities depend on this state funding to meet about $96 \%$ of their annual expenditure.

De Silva [23] infers that it has been difficult to promote university-industry collaborations in Sri Lanka, partly due to the absence of an overall university policy or support mechanisms to promote academic entrepreneurship. Any such small scale initiatives are mainly driven by individual academics. Furthermore, since all the Sri Lankan universities suffered from resource scarcities, there was no significant difference between universities.

Since University-industry interactions in Sri Lanka is a relatively recent phenomenon it has received limited proper leadership and direction or monitoring from within the university sector. Therefore, as suggested by Esham [24], it may be appropriate to consider the setting-up of a higher level body to provide direction to industry interaction cells setup at universities. This higher body should comprise representatives from both the universities and the industry in advisory capacities and should recruit personnel with strong leadership qualities and experience in industry and university affairs to provide the much needed guidance to the cells at universities. As far as industry is concerned, given the scale and diversity of local industries it is highly unlikely for each firm to come up with a liaison office of its own to interact with universities. Hence, Esham [24] recommended that the more feasible approach would be to setup liaison offices with the involvement of the industry association like the chambers of commerce and industry.

\section{B. University-industry interactions in Sri Lanka: empirical findings}

We have collected some empirical data from an exploratory study of university-industry collaborations in Sri Lanka in 2015. This section presents some of the key findings, which draw on the following: a questionnaire survey sent to universities; some pilot interviews conducted with university academic staff and a few company managers; some secondary data on national government sponsorship initiatives linked to university-industry interactions; a focus group type workshop held with employees from different industry sectors in Colombo (presented in Section C below).

Sri Lankan governments since 2005 formally started supporting university-industry interactions. In doing so, in 
2005, the University Grants Commission - Sri Lanka (UGC) introduced a Commission Circular promoting university-industry collaborations. In that, the UGC granted one year leave for senior university academics to work in any industrial establishment. In 2014, the government of Sri Lanka introduced a mechanism of triple tax deduction from the industry if they collaborate with universities in doing research [25]. As a result, universities such as University of Colombo, University of Kelaniya, and The Open University of Sri Lanka established formal units dedicated for university-industry collaborations. Third, the government allocated in its 2015 government budget funding some funds specifically for the following: (1) research and innovation in universities - pure sciences; (2) research that directly impact on communities; (3) post-doctoral research for academic staff just completed their PhDs; (4) local and international training for university academics; and (5) soft loans for academics to commercialize products developed through $\mathrm{R} \& \mathrm{D}$.

In the above context, we conducted a series of interviews and a questionnaire survey covering eight state universities of Sri Lanka to better understand the status of university-industry interactions. These eight universities were selected after our preliminary investigations that led to exclude seven universities due their lack of involvement in such types of interactions. Of the eight universities, four were established during the period of 1940 to 1960 , three were established during the period of 1970 to 1980 , and one was established after 1999. One university can be identified as located in a rural area while the remaining seven universities are located in urban areas of the country. For our questionnaire survey, the key senior academics (professor and senior lecturer grades) involved in university-industry interactions responded. We covered the faculties of applied sciences, medicine, engineering, computer science and information technology in conducting interviews and the survey. The total responses we received for our comprehensive questionnaire was 43, of which 42 per cent identified their respective universities interactions with the industry as 'much better' while 52 per cent identified this activity as 'good'.

Our questionnaire survey responses highlighted some key motivations in establishing university-industry linkages in Sri Lanka. For example, in relation to main modes of collaboration with industry currently being undertaken by universities, the university respondents rated 'student placement in industry' and 'consultancy to industry by Academic staff' as the most significant modes of collaboration (see Table I). The next most important modes of collaboration were seen as 'research contracted to university staff' and 'training of industry staff at university'.
TABLE I.

\begin{tabular}{|lc|}
\hline \multicolumn{2}{|c|}{$\begin{array}{c}\text { Main mode of collaboration link with industry (ranked according } \\
\text { to response rate) }\end{array}$} \\
\hline Mode of collaboration & $\begin{array}{c}\text { \% of responses } \\
\text { (choose as many boxes as possible) }\end{array}$ \\
\hline Student placements in industry & 96 \\
Consultancy to industry by Academic staff & 93 \\
Research contracted to university staff & 77 \\
Training of industry staff at university & 77 \\
Joint resaerch project/ or joint publication & 73 \\
Industry staff on visting placement at university & 65 \\
Joint conference or seminar event & 63 \\
Licensing technologies (e.g. patents) to industrial firm & 58 \\
\hline
\end{tabular}

In terms of factors that motivate universities to consider establishing collaborative links with industry, as shown in Table II, the university respondents rated (1) 'to access industrial feedback for graduates and curriculum development' as the main motivating factor. The next most important factor was that collaboration with industry was seen as giving universities (2) 'access to complementary expertise in industry'. Also significant was that collaboration with industry provided an opportunity (3) 'to train students in an industrial environment'. The next most important motivations were (4) 'to make a contribution to country's economy' and (5) 'to find an exploitation outlet for research capabilities'.

TABLE II.

\begin{tabular}{|lc|}
\hline \multicolumn{2}{|c|}{$\begin{array}{c}\text { Factors in motivating collaborative links with industry (ranked } \\
\text { according to mean value) }\end{array}$} \\
\hline Motive & Rank \\
\hline To access industrial feedback for graduates and curriculum & \\
development. & $(1)$ \\
To access complementary expertise in industry. & $(2)$ \\
To train students in industrial environment. & $(3)$ \\
To make a contribution to country's economy. & $(4)$ \\
To find an exploitation outlet for research capabilities. & $(5)$ \\
To access state of the art equipment and facilities. & $(6)$ \\
Collaboration is a strategic institutional policy. & $(7)$ \\
To get industrial funsing. & $(8)$ \\
Government policy and/ or political pressure. & $(9)$ \\
\hline
\end{tabular}

In terms of the most important mechanisms used for establishing collaborative links with industry, as shown in Table III, the most highly ranked mechanisms used are as follows: (1) 'access to specialized technical reports, equipment and industrial R\&D'; (2) 'participation in research contract and joint research'; (3) 'invention originating in university taken up by existing industrial companies'; (4) 'analysis and testing in industry'; (5) 'consultancy to industry by academics'. 
TABLE III

\begin{tabular}{|lr|}
\hline \multicolumn{2}{|c|}{$\begin{array}{c}\text { Mechanisms for establishing collaborative links with } \\
\text { industry (ranked by mean value) }\end{array}$} \\
\hline Mechanism & Rank \\
\hline & \\
Access to specialized technical reports, equipment and & $(1)$ \\
industrial R\&D. & $(2)$ \\
Participation in research contract and joint research. & \\
Invention originating in university taken up by existing & $(3)$ \\
industrial companies. & $(4)$ \\
Analysis and testing in industry. & $(5)$ \\
Consultancy to industry by academics. & $(6)$ \\
Personal contact via conference/ seminar type networking with \\
industrial staff.
\end{tabular}

Barriers to establishing collaborative links with industry were ranked somewhat differently from those for motivations and mechanisms shown in earlier tables, perhaps reflecting the lack of incentives for academics to pursue this line of activity (see Table IV). To calculate the means shown, a score of three was given to a 'very significant' barrier, two was given for a 'moderately significant' barrier, and one was given for a 'not significant' barrier. Hence the major barriers are seen as: (1) 'insufficient experience in New Product Development (NPD) and commercialization'; (2) 'cannot respond to needs of industry because our equipment base and facilities are insufficient'; (3) 'poor knowledge of industry relevant needs'; (4) 'differences in objectives of the university and company'; (5) 'work required by industry not always interesting for us'. Other barriers ranked lower than these five refer to institutional working arrangements of university staff perhaps not being conducive to taking on external collaborative tasks such as the ones listed in barriers 9 to 12 in Table IV.

\section{TABLE IV.}

\begin{tabular}{|c|c|c|}
\hline \multicolumn{3}{|c|}{$\begin{array}{l}\text { Barriers to establishing collaborative links with industry (ranked } \\
\text { by mean value) }\end{array}$} \\
\hline Rank & Barrier & Mean \\
\hline 1 & Insufficient experience in NPD \& commercialization. & 2.66 \\
\hline 2 & \multicolumn{2}{|l|}{ Cannot respond to needs of industry because our equipment base and } \\
\hline \multicolumn{2}{|r|}{ facilities are insufficient. } & 2.50 \\
\hline 3 & Poor knowledge of industry relevant needs. & 2.44 \\
\hline 4 & Differences in objectives of the university and company. & 2.41 \\
\hline 5 & Work required by industry not always interesting for us. & 2.31 \\
\hline 6 & No or few rewards for academics to work with industry. & 2.23 \\
\hline 7 & Restrictions on IPRs arising from collaboration with industry & 2.21 \\
\hline 8 & Industry does not consider universities to be a reliable partner. & 2.09 \\
\hline 9 & Working with industry does not influence academic promotions. & 2.00 \\
\hline 10 & Working with industry is not an expected role for us. & 1.97 \\
\hline \multirow{2}{*}{\multicolumn{2}{|c|}{ Government. }} & \\
\hline & & 1.93 \\
\hline 12 & Working with industry leads to delay of publications. & 1.78 \\
\hline
\end{tabular}

We conducted a few interviews with academics involved in university-industry interactions from a few of the Sri Lankan universities that had responded to our questionnaire survey. These interviews helped to confirm the following matters. First, at the very basic level all the universities irrespective of the Faculty (e.g., Engineering,
Medical, Applied Science, Management, Agriculture, Humanities) do provide industry oriented training programs. Some are courses leading to a qualification, PG dip, MSc, MBA, etc. In addition, they provide customized training programs to suit specific industry needs upon request. Further, some universities (both urban and rural) offer programs on an e-learning platform. Second, at a higher level of interactions, we identified one university that hosts some industry sponsored laboratories. The government agencies and the private sector often approach these laboratories for consultancy services, demonstrating another type of university-industry interaction. Third, all universities to some extent are involved in providing different types of dedicated services to the government agencies and the private sector, as consultancy services. For instance, Faculty of Medicines providing services to the Ministry of Health and many private sector firms with services such as biochemical, pharmacological, hematological, genetic, microbiological, pathological, parasitological, obstetric and gynecological. Additionally, Agriculture Faculties are providing services to the government agencies and the private sector, by performing multi-disciplinary $R \& D$ in plants and animals involving agricultural, medical, dental, aqua-culture, livestock, forestry, environment, indigenous medicine, and pharmaceuticals. Fourth, two universities, two government agencies and a Japanese university were involved in an internationally funded project on pollution control and remediation techniques for waste landfill sites in Sri Lanka.

In addition, we conducted a few interviews with some industry representatives. One official from a chemical manufacturing firm identified that charges for the services are reasonable and services are identified as accurate and reliable when the services are obtained from universities. An officer from an international NGO stated that they approached universities to get assistance in environmental assessment activities. Another officer from a government health related organization confirmed that medical faculties support government health initiatives. This officer also acknowledged that they have good relations with Humanities Faculties too, and gave evidence for taking assistance from a Humanities Faculty to conduct a broad based survey on health issues pertaining to internal migration covering a substantial portion of the country. However, industry representatives are unanimous in identifying the following as problems (or barriers) to maintaining collaborative relationships with universities: bureaucratic system prevailing in the universities; lack of experienced staff to deal with industry; university and industry objectives are different and considerable efforts are needed to match these objectives; universities are more concerned about their teaching rather than maintaining relations with industry; there is insufficient business know-how with universities. Some of the industry representatives also mentioned the following as more generic type of challenges to university-industry collaboration in Sri Lanka: lack of support for industrial research from universities or government; most industrial firms are reluctant to spend money on research; change of attitudes of all parties is very important; there should be a mechanism to link universities with SMEs. 


\section{Workshop with industry participants}

Some of the key issues arising from our Colombo Workshop session held in June 2015 with approximately 40 employees from different industry sectors also provided some helpful insights for our study. It was mentioned that universityindustry research partnerships, such as the types of interactions described above, enables companies to integrate corporate R\&D resources with university resources as part of a long-term partnership. This allows university research staff to benefit from insights into future business areas that firms are working in, while the sponsoring company gains access to the wider expertise available in the university community. The workshop participants highlighted a number of existing barriers and challenges that might inhibit university-industry collaborations in Sri Lanka. They also provided some suggestions of how to address and overcome some of these challenges. Within the scope of this paper, we highlight a few key issues arising from this workshop.

One issue mentioned by most of the workshop participants is that there firstly needs to be a culture developed within universities, which recognises the value of business and commercial engagement, by creating awareness among academics about the importance of commercialising their research results. Universities could properly utilize the contact with industry employees, who might be their ex-students, to identify needs of future continuing professional developments. At the same time firms from the private sector, as well as trade associations need to be made aware of the variety of linkages that can be created directly and indirectly with higher education institutions. Hence there appears to be a lack of understanding about what each of the partners can bring to such collaborations. This is partly linked to the fact that outputs of firms are seen to be more practical based and outputs from universities are less practical and perhaps more theoretical based. Hence there needs to be some mechanism to help improve the understanding of what the universities and firms can offer to each other. One suggestion made is to create a national institute that acts as an industry-academia coordination body that can highlight the benefits of university-industry collaborations to both universities and firms and it can set-up some forums that bring together these key actors at workshop/ conference type events to gain a better understanding of the needs of potential collaborators. Here it was also mentioned that the government can play an important role by helping to set-up such a national coordination body. Furthermore a number of practical suggestions were mentioned by the workshop participants. For example, universities could be more proactive in providing some form of knowledge transfer sessions to company staff on latest technological developments that some university research groups are working on. In return, the industry participants may be able to suggest some potential applications for taking the research results from universities into industry and potential commercialization. These types of forums might be organised around key themes that are of interest to the universities and industry, which could include environmental science, telecommunications, IT, sustainability, agricultural sciences, textile technology and a range of other areas. Postgraduate and undergraduate students could also act as facilitators of collaboration and other forms of knowledge transfer between universities and the private sector. For example, it was mentioned that some universities already offer some of their students' opportunities to implement some of their research projects with industry partners, so this could be expanded in the future. Where feasible, some university departments may consider working closely with industry for assistance with curriculum development whereby students are developing the type of skills that will help them to secure graduate jobs after completing their undergraduate studies as industrial firms would be able to benefit from hiring students with both academic and practical related skills.

\section{ANALYSIS AND DISCUSSION}

Many universities in developed countries and some in developing countries have created Technology Transfer Offices (TTOs) to deal with issues related to patenting, licensing and new venture creation based on university owned intellectual property targeted at closing the gap between invention and innovation in a triple helix type setting. Hence when initiating university-industry collaborations in developing countries, the key actors or government agencies involved with this type of initiative should perhaps examine any evaluation reports from countries that have TTOs to learn about the governance structure of the TTOs within a university setting, how effectively they have helped to spin-out companies and technology licenses from universities. These types of policy instrument evaluations may also shed some light on the firm's objectives to collaborate with universities. For example, is the remit classified as research, education, technology transfer, dissemination, networking or any other objective? These objectives might be viewed as investments in specific collaborative activities with a university and the expected values could be compared with the firm's financial commitment and other forms of in-kind support, to evaluate how the firm perceived such types of collaboration. These issues are linked to the point that both parties (i.e. the firm and the university) must be well aware of the potential pitfalls of university-industry collaboration before entering into such agreements. A previous U.K. based survey identified 'divergence of objectives' between the university and industry participants as the most frequently cited problem area in university-industry collaborations [26]. The divergence could be caused by changes in priorities on the industrial firm side, sometimes driven by changes in management structure or ownership, or on the academic side, driven by cultural factors that may steer the research in a different direction. To help mitigate this problem, the sponsor companies should try to manage the relationship better and more carefully over time.

As mentioned in our empirical findings earlier, there are a few fledgling initiatives where industry sponsored laboratories have been set-up in one university. If other universities in Sri Lanka are to follow this type of initiative there is a need for a 'collaboration champion' to drive this type of strategic partnership and this person could be from the university or from the company. Hence, this points to the fact that the focus of university-industry collaborations, especially in a developing country context, should be on projects that can be managed, and whose results can be implemented by the 
collaborating partners given their limited capabilities. If the remit of such projects might be too complex or uncertain, then the risk of failure and loss of trust is very high while the potential of valuable outcomes remains rather low. In addition, as mentioned by Schiller and Lee [27], individual actors and personalized capabilities are expected to be of particular importance in meaningful university-industry collaborations because general institutional trust does not exist among science and industry in many developing countries yet. Also advanced capabilities that help to solidify such linkages are not yet widely spread among actors in science and industry. Hence outstanding individuals (e.g. 'collaboration champion'), which might be researchers and administrators at universities, entrepreneurs of SMEs, and managers and top engineers in large firms, have to play a more prominent role to help provide the necessary institutional and financial resources to demonstrate the mutual benefits of university-industry collaboration to others.

Some university-industry collaborations can be viewed as a strategic partnership for the industrial firms as it offers a number of benefits. One major benefit is that the research collaboration may lead to work on developing technologies and product prototypes that might not currently exist, enabling the industry partner to target potential new markets. Similarly, university academics and research staff can benefit from longer-term collaborations by gaining a better appreciation of the business environment complexities that the industry partner firm is immersed in. Some industrial firms considering investment in more long-term university-industry collaborations are likely to want to know how they could measure the success of entering into this type of partnership. Perkmann, Neely and Walsh [28] state that a suitable measure for the emergence of valuable new ideas from such universityindustry collaborations is the number of new early-stage projects that have come about as a result of the alliance. Hence this is one impact of the collaboration. A second measure for impact can be represented by the weighted number of solution concepts generated during the alliance, such as for instance new technical architectures informing the design of systems. Thirdly, the incidence of innovations may be accounted for by the impact of collaboration activities on ongoing $R \& D$ programmes or even the design of new or improved products or projects. Another type of impact consists of benefits such as recruiting trained graduate and post-graduate students, building wider networks within the academic and industrial communities and adoption of new techniques, methods or approaches within the firm.

\section{CONCLUSION}

Reflecting on findings from our empirical research undertaken in Sri Lanka, we consider that the technological demand of industrial firms to universities in developing countries is different from that experienced in developed countries, but not essentially weaker or less relevant. Usually the collaborations are not necessarily concerned with technological innovation in a strict sense, but more with adaptation, enhancement, incremental change, and adjustment to local circumstances. We could also postulate that resource constraints in developing countries do not completely inhibit university-industry interactions. In fact, some academics do actively attempt to overcome various resource barriers. Hence this demonstrates that there are possibilities and potential opportunities open to those academics, with the right level of institutional support and backing, to initiate such linkages.

In Sri Lanka and some other developing countries, universities are not yet in the business of starting up new companies, neither is it their core mission to manage start-up companies. They are however, part of the larger community, and they perhaps need to acknowledge that they have a third mission, which encompasses the need to contribute to the regional economic development. This of course requires the government to allocate funding and other support to public universities in order for the universities to fulfil the third mission. Typically there is a lack of infrastructure, skills and resources required to support academic entrepreneurship and academic-industry collaborations.

Our empirical research findings are based on a single case study approach (i.e. the empirical research evidence was gathered in Sri Lanka, which is seen as the country case study here) in order to explore an under researched area [29]. Concurring with other single case study based research outputs like for example, Zott, Amit and Massa [30], the emergent nature of university-industry collaborations in a developing country like Sri Lanka presents the need for exploratory research in this area. Therefore, whilst generalisations cannot be made across other developing country contexts, the findings reported in this paper can be reinterpreted and reconstructed in other developing country contexts. This presents opportunities for further research to explore how some of the universityindustry interactions might already have been initiated in other developing countries and whether these have been evaluated to establish any innovation and entrepreneurship type impacts.

\section{ACKNOWLEDGMENT}

This paper is based on research supported by the British Academy's International Partnership and Mobility Scheme IPM 2014.

\section{REFERENCES}

[1] H. Etzkowitz and L. Leydesdorff, "The dynamics of innovation: from National Systems and Mode 2 to a Triple Helix of universityindustry-government relations," Research Policy, vol. 29(2), pp. 109-123, 2000.

[2] H. Etzkowitz, "Innovation in innovation: The triple helix of university-industry-government relations," Social Science Information, vol. 42(3), pp. 293-337, 2003.

[3] V. Mangematin and L. Nesta, "What kind of knowledge can a firm absorb?," International Journal of Technology Management, vol. 18(3), pp. 149-172, 1999.

[4] A. Morrison and R. Rabellotti, "The role of research in wine: the emergence of a regional research area in an Italian wine production system," International Journal of Technology and Globalisation, vol. 3(2), pp. 155-178, 2007. 
[5] Y. S. Lee, "The sustainability of university-industry research collaboration: an empirical assessment," The Journal of Technology Transfer, vol. 25(2), pp. 111-133, 2000.

[6] J. L. Furman and M. MacGarvie, "Academic collaboration and organizational innovation: the development of research capabilities in the US pharmaceutical industry, 1927-1946," Industrial and Corporate Change, vol. 18(5), pp. 929-961, 2009.

[7] A. Arundel and A. Geuna, "Proximity and the use of public science by innovative European firms," Economics of Innovation and New Technology, vol, 13(6), pp. 559-580, 2004.

[8] K. Pavitt, "Innovation processes," in The Oxford Handbook of Innovation, J. Fagerberg, D. Mowery and R. Nelson, Eds. Oxford: Oxford University Press, 2005, pp. 86-114.

[9] K. Malik, L. Georghiou and B. Grieve, "Developing new technology platforms for new business models: Sygenta's partnership with the University of Manchester," ResearchTechnology Management, vol. 54(1), pp. 24-31, 2011.

[10] M. D. Santoro and A. K. Chakrabarti, "Firm size and technology centrality in industry-university interactions," Research Policy, vol. 31(7), pp. 1163-1180, 2002.

[11] A. N. Link and J. Rees, "Firm size, university based research, and the returns to R\&D," Small Business Economics, vol. 2(1), pp. 2531, 1990.

[12] R. Fontana, A. Geuna and M. Matt, "Factors affecting universityindsutry R\&D projects: The importance of searching, screening and signalling," Research Policy, vol. 35(2), pp. 309-323, 2006.

[13] M. Aamir and K. Zaman, "Review of Pakistan pharmaceutical industry: SWOT analysis," Int. Jnl. of Business \& Information Technology, vol. 1(2), pp. 114-117, 2011.

[14] T. Bashir, K. Khan, and K. Malik, "The innovation landscape of Pakistan's North West Frontier Province," Science and Public Policy, vol. 37(3), pp. 181-191, 2010.

[15] A. Gul and A. Ahmad, "Perspectives of Academia-Industrial Linkage in Pakistan: An Insight Story," Science, Technology and Development, vol. 31(2): pp. 175-182, 2012.

[16] S. M. Afzal, K. F. Ahmad, M. I. Qureshi, K. Zaman and N. Khan, "Empirical analysis of university-industry R\&D collaboration: Evidence from Pakistan," Management Science Letters, vol. 4(8), pp. 1725-1740, 2014.

[17] I. Patarapong and S. Peerapol, "Foreign direct investment in R\&D in Thailand: Evolution and challenges," Paper presented at ASEAN/UNCTAD Seminar on Attracting Quality FDI, Bangkok, 6 May, 2005.
[18] S. Sutthijakra and P. Intarakumnerd, "Role and capabilities of intermediaries in university-industry linkages: A case of hard disk drive industry in Thailand," Science, Technology and Society, vol. 20(2), pp. 182-203, 2015.

[19] P. Brimble and R. F. Doner, "University-industry linkages and economic development: The case of Thailand," World Development, vol. 35(6), pp. 1021-1036, 2007.

[20] D. Schiller and I. Liefner, "Higher education funding reform and university-industry links in developing countries: the case of Thailand," Higher Education, vol. 54(4), pp. 543-556, 2007.

[21] Bureau of Economic \& Business Affairs, "2014 Investment Climate Statement - Sri Lanka”, U.S. Department of State report, 2014. [Accessed online on 18 August 2015: www.state.gov/e/eb/rls/othr/ics/2014/227229.htm ].

[22] UNESCO Report, UNESCO Country Programming Document for Sri Lanka: 2013-2017, New Delhi: UNESCO, 2013.

[23] L. R. De Silva, Academic Entrepreneurship in a Resource Constrained Environment, PhD Thesis: University of Manchester, 2012 (unpublished).

[24] M. Esham, "Strategies to develop university-industry linkages in Sri Lanka," National Education Commission Sri Lanka, Study Series No. 4 (2007/2008), March 2008.

[25] University Grants Commission - Sri Lanka. [Accessed online on 20 August 2015: www.ugc.ac.lk/ ].

[26] J. Howells, M. Nedeva and L. Georghiou, "Industry-Academic Links in the UK," Final Report to Higher Education Funding Council for England, HEFCE Ref. 98/70, Bristol: HEFCE, 1997.

[27] D. Schiller and K. Lee, "Are university-industry links meaningful for catch up? A comparative analysis of five Asian countries," in Developing National Syatems of Innovation, E. Albuquerque, W. Suzigan, G. Kruss and K. Lee, Eds. Cheltenham: Edward Elgar, 2015, pp. 55-92.

[28] M. Perkmann, A. Neely and K. Walsh, "How should firms evaluate success in university-industry alliances? A performance measurement system,” R\&D Management, vol. 41(2), pp. 202-216, 2011.

[29] R. Yin, Case Study Research: Design and Methods. London: Sage, 2009.

[30] C. Zott, R. Amit, and L. Massa, "The business model: recent developments and future research," Journal of Management, vol. 37, pp. 1019-1042, 2011. 